Journal of Southeast Asian

\title{
"Shes American Now, I Dont Like That": Gendered Language Ideologies in a Laotian American Community
}

Daryl Gordon

dgordon@adelphi.edu

Follow this and additional works at: https://docs.lib.purdue.edu/jsaaea

Part of the Asian American Studies Commons, and the Critical and Cultural Studies Commons

\section{Recommended Citation}

Gordon, Daryl (2009) "'Shes American Now, I Dont Like That": Gendered Language Ideologies in a Laotian American Community," Journal of Southeast Asian American Education and Advancement: Vol. 4 : Iss. 1, Article 1.

DOI: $10.7771 / 2153-8999.1092$

Available at: https://docs.lib.purdue.edu/jsaaea/vol4/iss1/1

This document has been made available through Purdue e-Pubs, a service of the Purdue University Libraries. Please contact epubs@purdue.edu for additional information.

This is an Open Access journal. This means that it uses a funding model that does not charge readers or their institutions for access. Readers may freely read, download, copy, distribute, print, search, or link to the full texts of articles. This journal is covered under the CC BY-NC-ND license. 


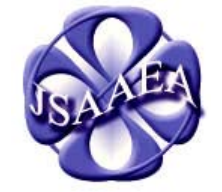

Volume 4 (2009)
Journal of Southeast $A$ sian $A$ merican

Education \& Advancement

WWW.JSAAEA.org
A peer-reviewed

scholarly journal

published by the

National Association

for the Education \&

Advancement of

Cambodian, Laotian,

and Vietnamese

Americans (NAFEA)

\title{
“She's American Now, I Don't Like That": Gendered Language Ideologies in a Laotian American Community
}

\author{
Daryl Gordon \\ Adelphi University
}

\begin{abstract}
As gender identities have shifted within the Laotian American community, perceptions of English proficiency have emerged as a site in which complex ideologies about gender identity are explored and contested. While Laotian women experience expanded opportunities for enacting their gender identities through wage labor and access to education, Laotian men experience a narrowing of opportunities, having lost traditional sources of power such as land ownership and high status professions. Laotian men's enactment of a discourse of nostalgia and the development of language ideologies, specifically the belief that they are more proficient English speakers than women, play an important part in men's attempt to mitigate this loss of status. At the heart of these ideologies about language is an assumption that men's greater proficiency in English allows them to create a seamless transition between their role as family leader and provider in Laos and a similar role within the radically changed gender landscape of the United States.
\end{abstract}

The transition from rural Laos to cities in the United States was difficult and jarring for many Laotian refugees. Contemplating the enormous changes experienced by Laotian families, I am reminded of Ouma ${ }^{1}$, a participant in this ethnographic study, giving me directions to her parents' house as I prepared to leave for Laos. Sitting in her small rowhouse in Philadelphia, Ouma instructed me, "Take the road from Paksong to a village called 'Sipsong Gilo" (Twelve Kilometers). Ask for, "Me Yen, Paw An, lugsaw yu Amelika" (Mother Yen, Father An, their daughter lives in America). When I inquired about a last name or address, Ouma responded that there were no house numbers in the village and last names were rarely used.

Upon my arrival in Paksong, I followed her directions and to my amazement, I found her parents' house easily. The contrast between the rural village in which she grew up, where thatch-roofed houses were built on stilts providing shelter for the family's water buffalo below, and her current home in a densely populated urban neighborhood, could not have

SOMIERIIGHISRESEFVEDReaders are free to copy, display, and distribute this article, as long as the work is attributed to the author(s) and the Journal of Southeast Asian American Education \& Advancement, it is distributed for non-commercial purposes only, and no alteration or transformation is made in the work. More details of this Creative Commons license are available at http://creativecommons.org/licenses/by-nc-nd/3.0/. All other uses must be approved by the author(s) or JSAAEA. 
been more vivid. That experience helped me to conceive of the enormous distances traveled by Laotian refugees as they entered urban communities in Philadelphia, where there were no rice paddies or coffee farms and high rates of crime and violence were common.

The distances traversed in terms of cultural practices and gender identities were similarly vast and, from the perspective of Laotian refugees, unimaginable. The deeply divisive nature of gender identity shifts became apparent to me when a male student in the ESL class I taught at the Lao Assistance Center described his experience of these shifting gendered cultural practices. His wife now went out at night and had begun openly dating an American-born co-worker. She explained this radical shift in gendered cultural practice by saying that she was "following the American way." While certainly most native-born Americans would similarly disapprove of this conduct and disagree that it is an accepted American cultural practice, this Laotian man conflated these gender identity shifts with American identity and was frustrated and bewildered about the conduct of Laotian women in the United States. He told me, "She says she’s independent. She's American now. She can do what she wants. I say I don't like that.”

My research within the Laotian American community documents the ways in which changing gender identities contribute to the formation of language ideologies. In this study, perceptions of English proficiency emerged as a site in which complex attitudes and ideologies about gender are explored and disputed. While Laotian women experience enhanced opportunities for enacting their gender identities through access to education and wage labor, Laotian men often experience a narrowing of opportunities, as they have lost traditional sources of power, such as land ownership, high status positions as soldiers, and the ability to be the sole economic supporter of the family. The development of language ideologies, specifically the belief that men are more proficient English speakers than women, plays an important part in men's attempt to mitigate this loss of status. At the heart of these ideologies about language is an assumption that men's greater proficiency in English allows them to create a seamless transition between their role as family leader and provider in Laos and a similar role in the United States.

However, this dominant language ideology masks a much more complex situation of language proficiency and wage earning. In the United States the lack of transferable skills and limited English proficiency restrict the majority of Laotian workers to positions in agricultural labor or in non-union factories with little need for or access to English. Laotian women have entered the wage labor force in large numbers, are often employed workplaces alongside men, and their salaries are a critical part of the family's income. Of the five families which were the focus of this study, three women were more proficient in English than their husbands and four of the five women worked as wage earners outside the home. ${ }^{2}$ Language ideologies regarding men's greater control of English allow Laotian men to position themselves as more capable providers than women and this, in turn, serves to assuage the consequences of the gender identity shifts experienced in their families.

\section{Gender Role Shifts in Migration}

Research in the field of migration and gender (Camino \& Krulfeld, 1994; Cha, 2005; Foner, 1999; Haddad \& Lam, 1994; Julian, 2004; Zhou \& Nordquist, 1994) has documented dramatic gender identity shifts within a range of immigrant and refugee communities. Studies among Southeast Asian refugee communities have documented gender role shifts and the 
development of greater autonomy for women upon migration to the United States. Kibria's (1990) study demonstrates the effects of migration on gender identity and power in Vietnamese-American communities, revealing the ways in which relative economic resources of men and women have shifted in the family. As women now earn money through wage labor and men's jobs are more unstable and lower-paid in the United States, men cannot support the family with their wages alone, as they had in Vietnam. Ui (1991) calls attention to the loss of traditional gender roles for Cambodian men in the United States, demonstrating that while many tasks which are traditionally performed by women, such as housework and childcare, endure in a new setting, Cambodian men have lost many of the traditional aspects which award them high status. In the United States they own no land, experience high rates of unemployment, and have no official leadership office to aspire to. Julian's study (2005) explores the ways that Hmong women resist, challenge, and create new constructions of Hmong femininity in the United States. She demonstrates that these multiple and often conflicting notions of Hmong femininity are conceptualized differently among first, 1.5, and second generations of Hmong women in the United States.

Unfortunately, despite the growing body of research in migration and gender in diverse immigrant and refugee communities, few studies have been conducted among Lowland Lao (or Lao Lum) families in the United States. Krulfeld's (1994) chapter examines how gender roles are reinterpreted within a Lao-American Buddhist Temple, an important exception to this dearth of research among Laotian American communities. Also, my research with Laotian American families in Philadelphia highlights the ways in which gender role shifts create new opportunities for women to learn and use English as a second language (Gordon, 2003; 2004).

Research in the area of gendered language socialization has contributed to a more complex understanding of gender identity and its role in second language socialization within culturally heterogeneous and multilingual settings. The perspective of gendered second language socialization redefines what it means to learn a second language; more than simply a structure for communication, learners are acquiring social, cultural, and gendered norms along with procedures for interpretation within a new cultural landscape.

Researchers have explored how gendered ideologies about a second language influence a learner's investment in or resistance to learning. A number of studies conducted with Japanese learners indicate that English, in particular, is fundamentally linked to feminism and the opportunity for expanded gender roles for Japanese women. Kobayashi (2002) demonstrates that Japanese women are especially invested in English language learning, as it offers the opportunity of travel and work in English-speaking countries, which offer more expansive gender identities for women. McMahill's (2001) study of female Japanese learners in a feminist EFL class finds that English acquisition provides Japanese women with an opportunity to re-assess gender ideologies and to use English as a language of empowerment. She writes that speaking in a foreign language such as English, while obviously entailing a struggle with another set of linguistic gender ideologies, may be seen as a gendered linguistic choice, which offers them a linguistic space for re-examining more consciously the norms of gendered speech and identity in Japanese (McMahill, 2001, p.312). Meynard-Warnick (2004) explores how gender identity mediates learners' decisions and opportunities for second language learning. Pavlenko (2001) connects second language learning with the transformation of gender performance and the reconsideration of gender ideologies. 


\section{Language Ideologies}

This article explores how language ideologies incorporate the traditional gender ideologies of the native country and examines how they change in response to new landscapes of gendered cultural practices and material realities. I turn now to a discussion of language ideology, beginning with a general discussion of the literature, followed by a review of research which examines gendered language ideologies in situations of language contact. Emerging from the tradition of linguistic anthropology, language ideology is a compelling concept for examining the intersection between language and gendered identity construction. Susan Gal (1998) suggests that the power of the concept of language ideology lies in its ability to integrate levels of social phenomena from macropolitical to microinteractional. Language ideology encompasses both social interaction and state policy as it can be understood both as verbalized discussion about languages, language varieties, or linguistic structures as well as the unspoken assumptions which are embedded in the structure of institutions and everyday interactions.

Linguists, anthropologists, and sociologists of language and education have offered varying definitions of language ideology, each of which emphasizes somewhat different dimensions of the construct. Silverstein (1979) places more emphasis on linguistic structure, defining linguistic ideology as "sets of beliefs about language articulated by users as a rationalization or justification of perceived language structure and use” (p. 193). Employing a stronger emphasis on the social aspect, Heath (1989) defines language ideology as "selfevident ideas and objectives a group holds concerning roles of language in the social experiences of members as they contribute to the expression of the group” (p. 393). Irvine (1989) emphasizes the role of language ideologies in perpetuating power relationships, defining them as a "cultural system of ideas about social and linguistic relationships, together with their loading of moral and political interests” (p. 255).

In the introduction to Language Ideologies: Practice and Theory (1998), Woolard examines the term "ideology," articulating four themes which recur as the term is used in different areas of research. Using her original discussion as a basis, I offer three themes which are consistently represented throughout the literature of language ideology. First, a language ideology concerns subjective representations, beliefs and ideas about a language, language variety, or speech genre. Second, an ideology represents itself as universally true, while it is derived from and responsive to the experiences and interests of a particular social position and is therefore directly linked to inhabitable positions of social, political, and economic power. Finally, while a language ideology serves in the struggle to acquire or maintain power, it contains a component of distortion or mystification which allows it to appear authentically and universally factual.

Much of the research in the area of gendered language ideologies has been conducted in language contact, rather than migration, contexts. Studies conducted by Spedding (1994) and Harvey (1994) in bilingual communities in Peru and Bolivia, respectively, demonstrate women's preference for indigenous languages, as a marker of insider status, while men use Spanish to index autonomy and an orientation toward a Spanish-speaking world of trade and wage labor. Gal's (1979; 1989) classic study of German/Hungarian bilinguals in eastern Austria demonstrates how both language ideology and a shift from an agricultural economy to an urban, industrialized economy contributed to women's leading the language shift 
toward German. McDonald (1994) describes a language shift from Breton to French in an area of Brittany which was experiencing an economic shift to a wage labor economy similar to the one documented by Gal (1979).

Current research recognizes that multiple language ideologies exist within any community. Gal (1998) notes that while dominant language ideologies are often linked to the state or to an economically dominant class, ideologies are rarely monolithic or stable and can be contested by other groups. Hill's (1998) research provides an example of contestation of a dominant language ideology as Nahuatl women invoke a counterdiscourse which highlights their conflicting social and linguistic perspectives. Examining language ideologies of Mexicano (Nahuatl) and Spanish in Central Mexico, Hill finds that older, more powerful men invoke a discourse of nostalgia in which Mexicano indexes respect, tradition, agrarian practices, and filial obedience, while Spanish indexes disrespect and rudeness. Hill writes that "the discourse of nostalgia claims that Mexicano dialogues are inextricably linked to a desirable social order of the past, and particularly to respect” (p. 72). However, women and younger, less powerful men invoke a counterdiscourse in which Mexicano is linked to poverty and lack of education, while Spanish indexes education, progress, and change.

In this article, I argue that a similar discourse of nostalgia is invoked by men in the Laotian American community, in which they, like Nahuatl men, harken back to a more desirable social order in the past. For Laotian American men, this social order is represented by a time before political turmoil resulted in the exile from Laos, where men held positions of higher status derived from positions as land owners and soldiers, as well as gender ideologies which explicitly advocated men's authority within the family. Laotian women, while acknowledging the shifts in gender ideology that have accompanied migration, do not participate in this discourse of nostalgia, emphasizing instead the gender inequality within traditional Laotian gender relations.

This discourse of nostalgia which is consistent with a traditional Laotian gender ideology is evident within men's metadiscourse regarding English language proficiency, as English language proficiency becomes iconic of male authority and position as breadwinner in the family. This language ideology contains an element of mystification, as it allows men to ignore the realities of their changed economic landscape. Some Laotian women, however, adopt a counterdiscourse regarding English proficiency, highlighting access to English as a means to greater autonomy and authority within family and community.

In the following section, I provide background on the Laotian migration to the United States in order to orient the reader to the history and demographics of the Laotian community in the United States. This section is followed by a discussion of my entry into the Laotian American community in Philadelphia and methods of ethnographic data collection and analysis. Next, I present comments from Laotian American research participants demonstrating Laotian men and women's experiences of the radically shifting gender identities experienced in the United States, followed by an analysis of how these shifts result in a dominant language ideology invoked by Laotian men, and a counter-discourse articulated by Laotian women.

\section{Background on Laotian Migration}

Laotian refugees settled in the United States as part of a massive influx of more than one million Southeast Asians from Vietnam, Cambodia and Laos, who sought refuge in the 
United States after the end of the Vietnam War in 1975. Census figures indicate that 198,203 Lowland Lao individuals currently reside in the United States; ${ }^{3}$ 2,536 Laotian individuals are reported to live in Pennsylvania, predominantly in the Philadelphia metropolitan area (Niedzwiecki \& Duong, 2004). When the majority of Laotian refugees entered the Philadelphia area in the 1980s, Philadelphia experienced significant deindustrialization and the loss of stable, unionized jobs during the post-war era. Laotian refugees entering the city in the 1980s found employment mainly in small plants involved in metalworking, woodworking, and garment production which are nonunion and often provide no worker benefits (Goode, 1994). The tenuous nature of employment for the vast majority of Laotian refugees continues to be reflected by current census figures for the Laotian community. Nineteen percent of Laotian families live below the federal poverty level, compared with $12 \%$ of the overall U.S. population. Thirty two percent of Laotian households report being linguistically isolated, meaning that no adult member of the family is able to speak English very well (Niedzwiecki \& Duong, 2004).

Laotian refugees entered the United States in three main waves. The first and second waves of refugees were composed of the elite groups, who were highly educated, from urban areas and had often worked closely with the American military. Third wave refugees, who entered the United States after 1985 comprised the largest group (Niedzwiecki \& Duong, 2004). These individuals were of the poorest socioeconomic classes, came from rural areas and had little exposure to formal education (Kelly, 1986). While all refugees experienced the trauma of leaving their homeland, third-wave refugees experienced the greatest hardships as they had the least familiarity with "western" culture, and their lives as subsistence farmers differed most markedly from the urban areas where they were relocated. All participants in this study entered the United States in the third wave, after 1985.

Third-wave refugees spent many years in Thai refugee camps before entering the United States. While both men and women experienced considerable upheaval in their normal lives in the refugee camps, men's roles shifted most dramatically. Cha's (2005) research conducted among Lao Lum and Hmong refugee women living in refugee camps in Thailand in the early 1990s reveals that Laotian families began to experience changes in traditional gender roles in Laos during wartime which continued in the refugee camps (Williams, 1990, as cited in Cha, 2005). Before the war, most Laotian families had been subsistence farmers, with both men and women cultivating rice and other crops and raising domesticated animals. When Laos became drawn into the Vietnam-American War and many Laotian men entered the military, families shifted to cash economy, with men being the primary main wage earner. Women took on the responsibility of caring for young children and older family members as families were forced to move continuously to avoid wartime hostility. Cha (2005) writes that this situation served to "lower the woman's status and selfesteem as she passed from the role of active partner in family maintenance to a marginalized figure in an increasingly political landscape in which cash, rather than labor per se, was the valued currency” (p. 10).

Women's roles shifted once again when families arrived in refugee camps. The necessity of women's domestic labor and their daily activities involving childcare, cooking and cleaning continued with little disruption in the camps (Hitchcox, 1993). However, the availability of new technology in the camp alleviated the burden of tasks such as fetching water and rice cultivation, which had consumed much of women's time and labor in Laos (Cha, 2005). Thus, women were able to engage in wage-earning activities, such as 
embroidery, weaving, sewing, marketing, and basketry. Laotian men, however, who had been subsistence farmers, hunters, or soldiers, lacked any access to the traditional gender roles, which had provided the framework of their lives (Hitchcox, 1993). Some men took on the women's traditional role of sewing, tailoring, and food marketing to contribute to the family's wages. Cha (2005) emphasizes, however, that the relative wage-earning ability of men and women shifted dramatically within the refugee camps, as "men were no longer able to provide even $50 \%$ of their family's basic needs ... refugee women had largely become the primary source of family cash income” (p. 12).

This radical change in gender roles influenced men's and women's attitudes toward repatriation or resettlement to a third country. In Cha's (2005) interviews, many Hmong and Lao Lum men expressed a desire for repatriation in order to maintain cultural and national identity, as well as to preserve cultural practices such as polygamy. Men feared a loss of status in resettlement. Women, on the other hand, stressed the financial rewards and opportunities available for their children in resettlement to a third country. Cha (2005) states that many Laotian women resisted repatriation, fearing that if their husbands were arrested or killed by the Laotian authorities, they would be forced to raise their children alone, likely in poverty. The gender role shifts, which Laotian families experienced during wartime and in refugee camps, set the stage for continued changes upon resettlement in the United States, where men and women experienced these transformations quite differently.

\section{Methodology}

My initial entry into the Laotian community began in 1994 when I conducted a FamilySchool Discussion Group in Philadelphia's Southeast Asian community. Pha, whose comments regarding shifting gender identities are presented later in this article, participated in that discussion group. After assisting Pha with an English language task, she invited me to her home and over baskets of steaming kau niau (sticky rice) and tam mak hung (green papaya salad), she told me stories about her homeland and her dreams and disappointments in this country. Pha also introduced me to other Laotian families which facilitated my entry into the community and made me a more familiar presence at events in the Laotian American community.

Formal data collection took place between 1997 and 2000 in an urban working class Laotian American community and in Laos. The process of ethnographic data collection took place in five distinct phases. Phase one (November 1997 - May 1998) involved participant observation and interviewing at the Lao Temple, a religious and cultural center of the Laotian American community. Phase two (June 1998 - August 1998) involved intensive Lao language and literacy study at the Southeast Asian Summer Studies Institute. Phase three (September 1998 - May 1999) involved practitioner research in an ESL/Citizenship class for Laotian adults, from which five principal participants were selected. The identification of the principal participants began Phase four (December 1998 - September 1999) during which I conducted focused participant observations and interviews in the homes, workplaces, and religious institutions of the principal participants. Phase five (October 1999 - October 2000) involved a year of research in Laos which allowed me to visit the families of two of the principal participants and to learn more about the cultural differences between Laos and the United States. Audiotaped interviews with research participants were conducted in English or 
with assistance of an interpreter. I transcribed the interviews myself and my intermediate proficiency in Lao allowed me to assess the accuracy of translations.

The data collection methods described above provided a broad and wide-ranging data corpus which facilitated triangulation of data sources. The data corpus contained: thirty-five interview transcripts; field notes from participant observation in the Lao Temple, the ESL/Citizenship class, research in Laos, and in the homes, workplaces and gathering places of principal participants; as well as documents from these sites. Data analysis for this study began by searching the data corpus in order to identify emergent themes and generate empirical assertions and analytical categories (Erickson, 1986). Data were manually coded using colored labels. A written record was kept for each analytic category noting the dates of field notes or interview transcripts along with a brief description or commentary on the event.

This article presents a subset of the data corpus, focusing on excerpts of interview transcripts of two men and two women. Pha and Ouma entered the United States in the mid1980s as married women with children. Pha did not work outside the home and received public assistance. Ouma worked part-time in a non-union factory alongside other Southeast Asian refugees and immigrants from other countries. During the course of this research, Ouma separated from her husband. Pha and Ouma both spoke English at an intermediate level, but were more proficient in English than their husbands and were responsible for most of the English language tasks in the home. Pha and Ouma's interview excerpts were selected for this article, as they were most outspoken of the Laotian women I interviewed about the shifts in gender identity in the United States.

Two Laotian men, Kham and Lung, were interviewed as part of this study, and their comments regarding gender role shifts are representative of many Laotian American men with whom I spoke. Kham frequently attended the Lao Temple where I taught English and conducted research. He entered the United States as a married man in the mid-1980s and was later divorced from his wife. While he earned his livelihood working in a factory, Kham's life revolved around Laos. He often talked of his role as a soldier in Laos and was passionate about the overthrow of the Pathet Lao, the current government of the Lao PDR. I met Lung through my work at the Lao Assistance Center, where he was as a job counselor who assisted Laotian clients in locating employment. Lung entered the United States in the late 1970s and was a former military officer in the Laotian government. Like Kham, his identity as a former soldier was a significant aspect of his identity. Above his desk stood a large, framed photo of himself as a young man in his military uniform. Lung and Kham both spoke English at an intermediate level of proficiency.

\section{Gender Identity Shifts}

Both Laotian men and women agree that gender identities have shifted dramatically upon migration to the United States. However, while women perceive these changes as expanding their opportunities through less restrictive gender identities, men experience these same changes as symptomatic of their loss of authority. In the following interview excerpt Kham describes the changes he observes in Laotian women in the United States and expresses nostalgia for Laotian gender ideologies which emphasizes men's authority and preeminence.

D: How do you think women change when they come to the United States? 
Kham: A lot different.

D: How?

Kham: That's hard! (Laughs) hard to tell you that. Because they coming here and you know, they say freedom. They want to go anywhere, they go. And they want to go any man, they go. Something like that. And that's why some, my people, they don't like it. Some people they don't like it.

D: So when you say they go to any man, do you mean that they're married, but then they have an affair or something with another man?

Kham: Uh huh. Yeah. Like that. And they do like American, go sleep with who or you want to do like that. That one-forget about it! I don't like it.

D: How do you think that women change like that? If in Laos, they....

Kham: They be good. Some people in Laos, they be good.

D: But they're the same people, just in a different country. How do they change?

Kham: I don't know. They say they coming here, the freedom. ... In Laos is not like that. You (women) have to be down a little bit. And the man ... they be like king, something like that-teaching. For the, for the man. The woman is down a little bit.

Kham emphasizes women's virtue ("in Laos, they (women) be good”) as opposed to their sexual permissiveness in the United States. ("They want to go to any man, they go.") Kham views "freedom" for women in the United States as the reason for these changes. His comments demonstrate that his perception of Laotian men's position as "kings” in Laos has changed dramatically within the United States. The themes which Kham articulates, of men's diminished authority and women's greater freedom, were echoed in the comments of many Laotian men.

Men's perception of their diminished authority over women and children were also reflected in their comments about the fact that domestic violence and child abuse are illegal in the United States. While Laotian women referenced laws against domestic violence as a part of their empowerment and safety in the United States, Laotian men's comments reflected an attitude that these laws were one more symptom of their eroding authority in the home. While no Laotian men I spoke with explicitly told me that hitting was acceptable or preferable, they often expressed astonishment that this behavior violated American law. In the following interview excerpt, Kham refers to his friend's recent argument with his wife. In this excerpt, Kham uses the term "talking-fighting” to describe a verbal argument which he contrasts with "fight, like a hit" by which he means that the husband physically strikes his wife. 
Kham: When they married and they hit the wife and fighting or something like that. They can’t do it.

D: They can't do it where?

Kham: Like uh, talking- fighting no problem. And they fight, like a hit, they can't do it. In here, in U.S., you know, law is different. Some people do it like that and they went to the jail. (laughs) Pay money for that! Yeah! A friend of mine it happened like that. He drunk. He come home, he fight with his wife. And then his wife scared, call police and police come, take him to jail, he pay money for that!

Kham emphasizes that physical violence ("fight like a hit") is not permissible in the United States. His friend's striking his wife results in his arrest. Kham expresses surprise that the man was imprisoned and required to pay a fine for this behavior. In Kham's comments, the police emerge as an institution that defends the wife's freedom while imprisoning the husband for behavior that Kham and other Laotian men may feel to be customary and appropriate under the circumstances. A number of Laotian men echoed Kham's sentiment that the police and other American social institutions contributed to men's loss of authority in the United States.

Some Laotian women are openly critical of traditional Laotian gender identities. This critique is most candidly expressed by second generation Laotian women, who are creating their identities in the United States and actively re-evaluating traditional Laotian gender ideologies. An example of this outspoken critique is the title of a chapter about gender identities in a writing anthology produced by Satjadham, a group of second generation Laotian American women and men. The chapter is entitled "Raising Boys to be Kings and Girls to be Slaves" (Satjadham, 1997, p. 17). While the focus of this study is first generation Laotian women who entered the United States as adults and had already formed relationships and gender identities in Laos, the comments of second generation young Laotian women provide a context in which to understand the tensions inherent between Laotian and American gender identities. While first generation women tended to be less openly critical of traditional Laotian gender identities, Ouma and Pha, the two participants who had the greatest proficiency in English, were the most vocal in their critique of traditional Laotian gender identities.

Laotian women often used the words "brave" or "strong" to describe their new gender identities in the United States. Ouma told me that “women can't be brave” in Laos like they are here in the United States. She defined bravery as enhanced ability to influence decisions regarding the family and greater autonomy to participate in activities outside the home. In the following excerpt, Pha describes the material and cultural resources in the United States which contribute to making Laotian women "stronger":

D: How women change so much (in the United States). It doesn't make sense to me.

Pha: Um, because in here, is have police, have friends, have, uh, communities, help them about make the, make the woman stronger. 
D: Huh, that's interesting.

Pha: But in Laos, nothing to help them about make them stronger. Only tell her, patient and patient, you is a woman, you is a mother. You have to patient. You cannot do anything except patient. But in here ... husband work, don't give me money, I can work, too. The companies want me to work, too, right?

Here Pha clarifies the effect of material resources on women's lives and on their ability to refuse the positioning of traditional gender identities. She mentions the importance of police, referring to a comment in an earlier conversation that Laotian women learn that they can call the police if they are being beaten by their husband or boyfriend, a resource not available to women in Laos. She also stresses the importance of friends, communities, and access to paid work which support women, enabling them to make new choices about how they realize their identities as women in the United States.

Pha observed that the economic and social resources available to Laotian women in the United States allow them to influence and transform traditional gendered cultural practices. An example of a cultural practice which Laotian women in the United States have affected is the cultural practice of polygamy. Throughout Laotian history, men frequently had multiple wives if they were able to support them. While the practice is currently illegal in the Lao PDR, legal restrictions are circumvented by men having a second girlfriend who has the status of a second wife; this woman is referred to as mia neu (little wife) while the first, legal wife is mia nyay (big wife). This custom continued to be practiced by Laotian men when they came to the United States. In the following excerpt, Pha discusses the way this tradition is changing in the United States, due to women's acquaintance with American law, as well as their ability to leave a husband and support themselves indepen-dently:

In heres, um, Laos, Laos people, is uh, man, right? Man is uh, they want to do the same thing, but the woman who's live heres long, about two, three years, they know about Americans law, and if husbands go out, have girlfriend or have second wife, something like that, and the wife's at home, they know about husband do like that. They impatient, they go out too. They have boyfriend, too. If husband say get divorced, they don't care. They get divorced.

Laotian women in the United States resist the traditional practice of polygamy through awareness of American laws, as well as less restrictive gender identities in the United States. Pha suggests that women may resist this practice by having an extramarital affair or getting a divorce, options not easily available to women in Laos, due to the economic and cultural constraints.

While many Laotian women value the expanded gender identities available to them in the United States, they are concerned and critical of the increasing rates of divorce within their community. Both men and women complained that shifts in family roles and gender identities have resulted in higher rates of separation and divorce. Men attribute rising rates of divorce within the Laotian American community to women's dramatic changes upon migration. One man commented that when Laotian families enter the United States, women "see everything different and they want to change the rules." 


\section{The Development of Gendered Language Ideologies}

Laotian men and women's differing perspectives on the gender identity shifts occurring in the United States developed into gendered language ideologies. The two quotations below demonstrate opposing opinions regarding gendered English proficiency and link language proficiency with family authority. The first quotation from Lung, a Laotian man, invokes a discourse of nostalgia and is representative of the dominant language ideology that man's greater language proficiency allows him to be the economic provider and family leader. The second, from Pha, a Laotian woman, demonstrates a counter-discourse that a woman's greater English proficiency may result in her assuming authority in the family.

The first quotation is representative of the dominant language ideology advanced by most Laotian men. In this interview, I ask him about the clients he sees and who tends to speak more English. Lung replies that men speak more English because they are the financial provider for the family:

D: Do you think that men or women tend to speak more English?

Lung: Men. Men speak more English for woman because a man they want to learn anything, take care whole family. Men ... find out everything. ... And men looking the job hard, too. They do everything for make family strong for money, everything for only man.

D: And how about women? Why do you think women ....

Lung: The woman something, they come behind men, is \#2 in my country. The man is take care of everything in the house, everything in the family. After father and then, mother. After mother, then big sister. They take care like that, stepby-step.

D: $\quad$ And how about for women ... why do you think ... Or do you think women want to learn English?

Lung: They want to learn for come behind men. Sometimes men they got trouble, the woman they come up. Try to help (if) they can ... American in here, I think the woman go learn a lot (more) than man. Man lotta play, I think, I not sure. But my (Laotian) people, the man be careful for looking the job. They go learn everything, they want to learn everything.

Lung outlines a very clear family structure in which the man has the major role as provider and decision-maker while the woman follows behind in a subordinate position. His comment closely echoes a Laotian proverb about gender- "The man is the elephant's front legs and the woman is the elephant's back legs." This proverb indicates that the man is the decision maker and the woman follows his lead, while emphasizing the necessity of family unity, as husband and wife are connected and function as a single unit. 
For Lung, English acquisition fits into and supports his vision of a traditional Laotian family structure, as men want to learn English in order to look for a job, and support and strengthen the family. Men's knowledge of English enables them to maintain their role as provider for the family. Knowledge of English is one of the criteria of being a good caretaker as it is connected to earning money and financially supporting the family. Women's acquisition of English does not threaten or interfere with men's authority in the family. In fact, by Lung's report, Laotian women seem to want to learn English in order to continue in their subordinate role in the family, "They want to learn to come behind men."

Perceptions about English function in a number of interesting ways in Lung's account. English proficiency is connected to a man's capacity to provide for his family and to obtain employment. Particularly interesting is Lung's emphasis on men's English ability enhancing their employability. In his capacity as a job counselor, Lung places both men and women in primarily low-wage positions in non-unionized factories and frequently received calls from employers complaining that the workers Lung had sent could not understand English. Lung often defended both men's and women's lack of English ability to employers, saying that they did not need English to perform their jobs which usually involved unskilled labor in factories. However, in the above quotation from Lung, English proficiency is one of the main ways in which Laotian men find jobs, support their families, and maintain their role as authority figures within the traditional Laotian family structure.

Lung's comments reveal a language ideology regarding English proficiency which is consistent with a traditional Laotian gender ideology. Men's greater English language proficiency acts to support and continue men's status within a radically transformed social and economic environment in which men's status and gender identity have been greatly transformed. In Lung's account, English proficiency becomes iconic of male authority and position as family wage earner. This language ideology contains an element of erasure or mystification, as it allows men to ignore the realities of their changed economic landscape. In the United States Laotian men lack access to ownership of land and are often employed in low-paid jobs; women's entry into wage labor has transformed the social and economic structure of the family, as their earnings contribute significantly to the family income.

Laotian women, however, adopt a counter-discourse regarding English proficiency, highlighting access to English as a means to greater autonomy and authority within family and community. In the following interview excerpt, Pha reacts to an observation by a female Cambodian refugee who asserts that immigrant women's higher English proficiency results in their increased authority and decision-making power within the family. Pha responds:

Yeah, because wife, right, know more English than husband, who know more English, that's person smarter than who don't know English. And then, so, she know more English, she can work good than her husband. She make more money. And she can decisions everything, control everything.

This quotation disrupts the family structure that Lung outlined in which the man is the provider and the family works as a unit. Pha connects English proficiency to a number of other attributes, including intelligence, ability to find a better job and earn more money, and to make decisions for and control the family. In this quotation, the woman is highlighted and individualized in a way very different from Lung's concept of the family as a unit with the 
man as its head. English acquisition becomes one way in which women obtain more authority within the family.

The quotations above demonstrate the ways in which English language proficiency is not only a marker of symbolic capital in interactions with the native English-speaking community, but an important marker within the community which connects to perceptions of family authority and visions of family structure within the new country. Lung's vision of a family unit with the husband as its undisputed leader cannot coexist with Pha's vision of a woman who "controls everything." This controversy about family leadership and dramatic shifts in gender identity occurring within this refugee community continue to be inscribed in these competing language ideologies regarding perceptions of gendered second language proficiency.

The discourse of nostalgia for traditional Laotian gender identities manifests itself in men's metadiscourse as English proficiency becomes a way in which men represent their identity as family authority and sole wage-earner, aspects of their identity which were true in Laos. This provides men with a sphere of power within a cultural landscape which has severely curtailed their authority, both economically and socially, while it has highlighted women's power and autonomy. Laotian women who employ the rhetoric of counterdiscourse interrupt the representations of the social order produced in the discourse of nostalgia by underscoring the ways that English acquisition has led to women's greater authority in family and autonomy in community.

\section{Conclusion}

The data presented in this article underscores the importance of exploring the ways in which gender ideologies become embedded within language ideologies about second language proficiency, as well as the ways in which a second language can be used to resist traditional gender identities and create new identities. Pavlenko (2001) maintains that learning a second language encourages the reconsideration of gender identities and roles which were considered the norm in the native country. About this connection between gender identity and language learning, she writes:

One does not simply learn a new set of grammar rules and apply them to new vocabulary; new discourses come with new ideologies and practices of embodiment. Does one flirt in this new space? And if yes, then how? What does dating mean? How does one become a parent if one's own models of parent-child relationship are no longer valid? Although these questions are disquieting to everyone who makes a transition into adulthood, the bewilderment is much more severe when linguistic and cultural transition is added to the normal sensitivities concerning intimacy and personal boundaries. (p. 149)

The Laotian American women and men who took part in this research are engaged in the process of second language socialization in a new land in which gendered cultural practices are markedly different from their childhood in Laos. While engaged in the process of language learning, they are also transforming and re-evaluating what it means to be a woman,

a man, a wife, a husband, a mother, or a father in the United States. Research into language 
ideologies and their connection to gender identities offers a perspective on the dramatic shifts taking place in immigrant and refugee families.

While the majority of gender research has focused on the experiences of women, these data demonstrate the painful and confusing shifts experienced by Laotian refugee men in the renegotiation of their gender identities. Identity theory has witnessed a growing interest in the construction of masculinity as an identity category, rather than an unproblematized norm against which femininity is analyzed. Researchers have explored the connections between masculinity and language use (Echeverria, 2003; Teutsch-Dwyer, 2001; Vitanova, 2004) in a range of language context settings. There is a need for further research in the area of men's experience of gender identity shifts in a migration context, involving men of diverse ethnic backgrounds and socioeconomic levels. Additionally, further research needs to be conducted with 1.5 and second generation Southeast Asian American men and women, who are negotiating the traditional gender identities of their parents while establishing new gender identities in the United States.

\section{End Notes}

${ }^{1}$ Names of organizations and individuals are pseudonyms.

${ }^{2}$ English proficiency levels discussed in this article were assessed based on oral proficiency in a series of conversations over the three year period of data collection. The assessment was based on standard elements of oral proficiency, including fluency, intelligibility, range of vocabulary, and syntactic accuracy, as well as communicative strategies such as circumlocution.

${ }^{3}$ While Laos is a diverse country with many ethnolinguistic groups, Lowland Lao are the majority ethnic group. Throughout this article "Lao" refers only to Lowland Lao individuals. While other ethnic groups from Laos, principally the Hmong, a highland ethnic group, migrated to the U.S. in large numbers, the discussion here is limited to Lowland Lao individuals.

\section{References}

Camino, L., \& Krulfeld, R. (1994). Reconstructing lives, recapturing meaning: Refugee identity, gender, and cultural change. New York: Gordon and Breach Publishers.

Cha, D. (2005). Hmong and Lao refugee women: Reflections of a Hmong-American woman anthropologist. Hmong Studies Journal, 6, 1-35.

Echeverria, B. (2003). Language ideologies and practices in (en)gendering the basque nation. Language in Society, 32(3), 383-413.

Erickson, F. (1986). Qualitative methods in research on teaching. In M. C. Wittrock (Ed.), Handbook of research in teaching ( $3^{\text {rd }}$ ed.). New York: Macmillan.

Foner, N. (1999). Immigrant women and work in New York City, then and now. Journal of American Ethnic History, 18(3), 95-113.

Gal, S. (1978). Peasant men don't get wives: Language and sex roles in a bilingual community. Language in Society, 7(1), 1-17.

Gal, S. (1979). Language shift: Social determinants of linguistic change in bilingual Austria. New York: Academic Press.

Gal, S. (1989). Language and political economy. Annual Review of Anthropology, 18, 345367.

Gal, S. (1998). Multiplicity and contestation among language ideologies: A commentary. In B. Schieffelin, K. Woolard, \& P. Kroskrity (Eds.), Language ideology: Practice and theory (pp. 3-47). New York: Oxford University Press. 
Goode, J. (1994). Polishing the rustbelt: Immigrants enter a restructuring Philadelphia. In L. Lamphere, A. Stepick, \& G. Grenier (Eds.) Newcomers in the workplace: Immigrants and the restructuring of the U.S. economy. Philadelphia: Temple University Press.

Gordon, D. (2003). "I'm tired. You clean and cook": Shifting gender identities and second language socialization in a Lao-American Community. Unpublished Doctoral Dissertation, University of Pennsylvania.

Gordon, D. (2004). "I'm tired. You clean and cook": Shifting gender identities and second language socialization. TESOL Quarterly, 38, 3.

Guttal, S. (1993). Strategies for the promotion of basic education for women and girls. Boston: World Education.

Haddad, T., \& Lam, L. (1994). The impact of migration on the sexual division of family work: A study of Italian immigrant couples. Journal of Comparative Family Studies, 25(2), 167-186.

Harvey, P. (1996). The Presence and absence of speech in the communication of gender. In P. Burton, K. K. Dyson, \& S. Ardener (Eds.), Bilingual women: Anthropological approaches to second language use (pp. 44-64). Providence, RI: Berg.

Heath, S. (1989). Language Ideology. In International Encyclopedia of Communications, (Vol. 2, pp. 393- 395). New York: Oxford University Press.

Hill, J. H. (1998). "Today there is no respect": Nostalgia, "respect", and oppositional discourse in Mexicano (Natuatl) language ideology. In B. Schieffelin, K. Woolard, \& P. Kroskrity (Eds.), Language ideology: Practice and theory (pp. 68-86). New York: Oxford University Press.

Hitchcox, L. (1993). Vietnamese refugees in Hong Kong: Behaviour and control. In G. Buijs (Ed.), Migrant women: Crossing boundaries and changing identities. Oxford, UK: Berg Publishers.

Julian, R. (2005). Hmong transnational identity: The gendering of contested discourses. Hmong Studies Journal, 5, 1-23.

Irvine, J. (1989). When talk isn't cheap: Language and political economy. American Ethnologist, 16(2), 248-267.

Kelly, G. (1986). Southeast Asians in the United States. In S. Chan (Ed.), Dictionary of Asian-American History. New York: Greenwood Press.

Kibria, N. (1990). Power, patriarchy, and gender conflict in the Vietnamese immigrant community. Gender \& Society, 4(1), 9-24.

Kobayashi, Y. (2002). The role of gender in foreign language learning attitudes: Japanese female students' attitudes toward English learning. Gender and Education, 14, 181197.

Krulfeld, R. (1994). Buddhism, maintenance and change: Reinterpteting gender in a LaoAmerican community. In Camino, L. \& Krulfeld, R. (Eds.) Reconstructing lives, recapturing meaning: Refugee identity, gender, and cultural change. New York: Gordon and Breach Publishers.

McDonald, M. (1994). Women and linguistic innovation in Brittany. In P. Burton, K. K. Dyson, \& S. Ardener (Eds.), Bilingual women: Anthropological approaches to second language use. Oxford, UK: Berg Publishers.

McMahill, C. (2001). Self-expression, gender, and community: A Japanese feminist English class. In A. Pavlenko, A. Blackledge, I. Piller \& M. Teutsch-Dwyer (Eds.), 
Multilingualism, second language learning, and gender (pp. 307-344). New York: Mouton de Gruyter.

Meynard-Warnick, J. (2004). "I always had the desire to progress a little": Gendered narratives of immigrant language learners. Journal of Language, Identity \& Education, 3(4), 295311.

Niedzwiecki, M., \& Duong, T. C. (2004). Southeast Asian American statistical profile. Washington, DC: Southeast Asia Resource Action Center (SEARAC).

Pavlenko, A. (2001). "How am I to become a woman in an American vein?": Transformations of gender performance in second language learning. In A. Pavlenko, A. Blackledge, I. Piller \& M. Teutsch-Dwyer (Eds.), Multilingualism, second language learning, and gender (pp. 133-174). New York: Morton \& Gruyter.

Pujolar i Cos, J. (1997). Masculinities in a multilingual setting. In S. Johnson \& U. H. Meinhof (Eds.), Language and masculinity (pp. 86-106). Cambridge, MA: Blackwell.

Silverstein, M. (1979). Language structure and linguistic ideology. In P. Clyne, W. Hanks \& C. Hofbauer, (Eds.), The Elements: A parasession on linguistic units and levels. (pp. 193-247). Chicago: Chicago Linguistic Society.

Spedding, A. (1994). Open Castilian, closed Aymara? Bilingual women in the Yungas of La Paz (Bolivia). In P. Burton, K. K. Dyson, \& S. Ardener (Eds.), Bilingual women: Anthropological approaches to second language use (pp. 30-43). Providence, RI: Berg.

Takaki, R. (1989). Strangers from a different shore: A history of Asian-Americans. New York: Penguin Books.

Ui, S. (1991). "Unlikely heroes": The evolution of female leadership in a Cambodian ethnic enclave. In M. Buraway (Ed.), Ethnography unbound: Power and resistance in the modern metropolis. Berkeley, CA: University of California Press.

Teutsch-Dwyer, M. (2001). (Re)constructing masculinity in a new linguistic reality. In A. Pavlenko, A. Blackledge, I. Piller, \& M. Teutsch-Dwyer (Eds.), Multilingualism, second language learning, and gender (pp. 175-198). New York: Mouton de Gruyter.

Vitanova, G. (2004). Gender enactments in immigrants' discursive practices: Bringing Bakhtin to the dialogue. Journal of Language, Identity, \& Education, 3(4), 261-277.

Woolard, K. (1998). Introduction: Language ideology as a field of inquiry. In B. Schieffelin, K. Woolard, \& P. Kroskrity (Eds.), Language ideology: Practice and theory (pp. 347). New York: Oxford University Press.

Zhou, M., \& Norquist, R. (1994). Work and its place in the lives of immigrant women: Garment workers in New York City's Chinatown. Applied Behavioral Science Review, 2, 187-211.

\section{About the Author}

Daryl Gordon is an assistant professor at Adelphi University's TESOL Program. She earned her doctorate in Educational Linguistics at the University of Pennsylvania. She has taught and designed curricula for ESL learners in the United States, Mexico, and the Lao PDR. Her research interests include gendered second language socialization, health literacy for ESL learners, and civic engagement for adult immigrants. 


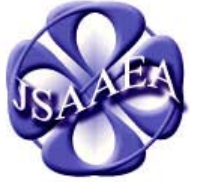

Volume 4 (2009)
Journal of Southeast Asian American Education \& Advancement WWW.JSAAEA.org

\section{Editor}

Dr. Wayne E. Wright

University of Texas, San Antonio

Associate Editors

Dr. Chhany Sak-Humphry

University of Hawaii

Dr. KimOanh Nguyen-Lam

California State University, Long Beach

Book Review Editor

Dr. Vichet Chhuon

University of California-Santa Barbara

Creative Works Editor

Phouang Hamilton

Washington Office of Superintendent of Public Instruction

Editorial Assistant

Mariana Kuhl

University of Texas, San Antonio
A peer-reviewed

scholarly journal

published by the

National Association

for the Education \&

Advancement of

Cambodian, Laotian,

and Vietnamese

Americans (NAFEA)

Comments and questions for the editorial staff may be directed to jsaaea@lists.sis.utsa.edu

\section{Editorial Review Board}

\author{
Dr. Carl L. Bankston III \\ Tulane University \\ Dr. Phala Chea \\ Lowell Public Schools \\ Dr. Changming Duan \\ University of Missouri, Kansas City \\ Dr. Nancy H. Hornberger \\ University of Pennsylvania \\ Dr. Peter Nien-Chu Kiang \\ University of Massachusetts, Boston \\ Dr. Stacey Lee \\ University of Wisconsin, Madison \\ Dr. Sue Needham \\ California State University, Dominguez Hills
}

Dr. Pollie Bith-Melander

Asian and Pacific Islander Wellness Center

Dr. George Chigas

University of Massachusetts, Lowell

Dr. Sophal Ear

U.S. Naval Postgraduate School

Dr. Samlong Inthaly

Minneapolis Public Schools

Dr. Kevin K. Kumashiro

University of Illinois, Chicago

Dr. David Chanpannha Ley

Montgomery County Public Schools

Dr. Bic Ngo

University of Wisconsin-Madison 


\author{
Dr. Max Niedzwiecki \\ Daylight Consulting Group \\ Dr. Clara Park \\ California State University, Northridge \\ Dr. Loan T. Phan \\ University of New Hampshire \\ Dr. Karen Quintiliani \\ California State University, Long Beach \\ Dr. Fay Shin \\ California State University, Long Beach \\ Dr. Yer J. Thao \\ Portland State University \\ Dr. Khatharya Um \\ University of California, Berkeley \\ Dr. Terrence G. Wiley \\ Arizona State University \\ Dr. Leakhena Nou \\ California State University, Long Beach \\ Dr. Mark Pfeifer \\ Texas A\&M University, Corpus Christi \\ Dr. Bounlieng Phommasouvanh \\ Minnesota Department of Education \\ Dr. Kalyani Rai \\ University of Wisconsin, Milwaukee \\ Dr. Nancy J. Smith-Hefner \\ Boston University \\ Dr. Myluong Tran \\ San Diego State University \\ Dr. Linda Trinh Vo \\ University of California, Irvine \\ Dr. Zha Blong Xiong \\ University of Minnesota \\ Dr. Kou Yang \\ California State University, Stanislaus

\section{Doctoral Student Editorial Review Board} \\ Keo Chea \\ University of Pennsylvania \\ Loan Dao \\ University of California, Berkeley \\ Ha Lam \\ Arizona State University \\ Monirith Ly \\ Texas State University \\ Rassamichanh Souryasack \\ University of California, Santa Barbara \\ Layheng Ting \\ State University of New York, Albany \\ Ravy Lao \\ University of California, Santa Barbara \\ Vanna Som \\ Harvard University \\ Giang Pham \\ University of Minnesota \\ Tinou Tran \\ University of Houston, Texas \\ Phitsamay Sychitkokhong Uy \\ Harvard University \\ Tinou Tran \\ University of Houston, Texas

\section{Loan Tran} \\ University of California, Santa Barbara
}

